\title{
INFLUENCE OF MECHANICAL ROOT RESTRICTION ON GAS-EXCHANGE OF FOUR PAPAYA GENOTYPES
}

\author{
ELIEMAR CAMPOSTRINI ${ }^{1,3}$ AND OSVALDO KIYOSHI YAMANISHI ${ }^{2}$
}

\author{
Setor de Fisiologia Vegetal, CCTA, Universidade Estadual do Norte Fluminense
}

\begin{abstract}
Four papaya genotypes, two from the 'Solo' group (Sunrise Solo TJ and Improved Sunrise Solo line 72/12) and two from the 'Formosa' group (Tainung 02 and Know You 01) grown in ultisol under field conditions in Macaé, RJ, Brazil, were used in this study. Two different effective depths $(E D)$ were determined in the area using a penetrographer with average soil moisture of $11.2 \%$. The area with $E D$ of $0.35 \mathrm{~m}$ with a maximum pressure of $4.12 \mathrm{MPa}$ for penetration was defined as an area with restriction $(W R)$ to root growth, while, the area with minimum $E D$ of $0.60 \mathrm{~m}$ and a pressure lower than $2.30 \mathrm{MPa}$ as an area with no restriction $(N R)$. The net $\mathrm{CO}_{2}$ assimilation rate $(A)$, stomatal conductance $\left(g_{s}\right)$, leaf temperature $\left(T_{l}\right)$, intercellular partial pressure of $\mathrm{CO}_{2}\left(\mathrm{c}_{\mathrm{i}}\right)$ and intrinsic water use efficiency $(I W U E)$ were evaluated for three consecutive days after irrigation. Mechanical root restriction affected gas exchange of the four papaya genotypes. All genotypes grown in the $W R$ area had lower $A, g_{s}$ and $\mathrm{c}_{\mathrm{i}}$ and higher $T_{l}$ than the same genotypes in the $N R$ area. All genotypes grown in the $W R$ area had high IWUE and Sunrise Solo TJ had the highest IWUE.
\end{abstract}

TERMS ADDITIONAL INDEX: Carica papaya L., photosynthesis, leaf temperature, stomatal conductance, intrinsic water use efficiency.

\section{INFLUÊNCIA DA RESTRIÇÃO DA RAIZ SOBRE AS TROCAS GASOSAS EM QUATRO GENÓTIPOS DE MAMÃO}

RESUMO: Neste estudo, quatro genótipos de mamão, dois pertencentes ao grupo 'Solo' (Sunrise Solo TJ e Sunrise Solo 72/12) e dois pertencentes ao grupo 'Formosa' (Tainung 02 e Know-You 01), foram cultivados num Argissolo Amarelo, em condição de campo, no município de Macaé, RJ, Brasil. A área de cultivo foi dividida em duas sub-áreas com profundidades efetivas (PE) distintas, determinadas com auxílio de um penetrógrafo a uma umidade média de $11,2 \%$. Área com restrição $C R$ apresentou $P E$ média de $0,35 \mathrm{~m}$ com esforço máximo de $4,12 \mathrm{MPa}$ para penetração, enquanto área sem restrição $(S R)$ apresentou $P E$ mínima de $0,60 \mathrm{~m}$ com esforço menor que 2,30 MPa. A taxa fotossintética líquida $(A)$, a condutância estomática $\left(g_{s}\right)$, a temperatura foliar $\left(T_{l}\right)$, a concentração interna de $\mathrm{CO}_{2}$ no mesofilo foliar $\left(c_{i}\right)$ e a eficiência intrínseca no uso da água $(I W U E)$ foram determinadas em três dias consecutivos após a

Received: 30.09.2000 - Accepted: 25.07.2001

1. Setor de Fisiologia Vegetal, Centro de Ciências e Tecnologias Agropecuárias, Universidade Estadual do Norte Fluminense, Campos dos Goytacazes, RJ. 28015 620, Brasil

2. Setor de Fruticultura, Faculdade de Agronomia e Medicina Veterinária, Universidade de Brasília, Brasília, DF, 70910970 , Brasil

3. Corresponding author: Tel. +55 24726 3751, Fax: +55 24726 3746; campost@ zappa.uenf.br 
irrigação. A restrição do crescimento do sistema radicular afetou as trocas gasosas dos quatro genótipos de mamoeiro. Na área $C R$, todos os genótipos apresentaram valores reduzidos de $A, g_{s}$ e $c_{i}$ e elevados de $T_{l}$, em relação aos genótipos crescidos na área $S R$. Todos os genótipos crescidos na área $C R$ apresentaram elevados valores de $I W U E$ e o genótipo Sunrise Solo TJ foi o que apresentou o maior valor de $I W U E$.

TERMOS ADICIONAIS PARA INDEXAÇÃO: Carica papaya L., fotossíntese, temperatura da folha, condutância estomática, eficiência intrínseca no uso da água.

\section{INTRODUCTION}

Soil physical limitations to root growth may arise from several sources, including soil compactation resulting from harvesting of a previous crop (Misra and Gibbons, 1996). Compacted soil that limits root growth may be the result of a naturally dense layer or fragipans, or a result of the forces applied to the soil by implements or animals (Unger and Kaspar, 1994). In Brazil, the soils with a dense sub-surface are classified as oxisols and ultisols (Resende et al., 1988). These soils represent a significant area for potential agricultural production because of their close proximity to areas of intense agricultural use in the southeast and to areas with accentuated rainfall and intense demand for agriculture in the northeast.

Soil characteristics that prevent root penetration or reduce root elongation rates can reduce plant development and yields, by limiting availability of water and nutrients. The degree of reduction of water and nutrients depends, to a large extent, on the soil depth at which the restriction zone occurs (Unger and Kaspar, 1994). In peach seedlings, root restriction reduced plant dry weight, the number of root apices, leaf number, shoot initiation, root extension, dry weight and root length, leaf area and water uptake by $30-60 \%$ (Richards and Rowe, 1977). Root restriction also reduced chlorophyll concentration in spreading euonymus (E. kiautschovica Loes 'Sieboldiana') (Dubik et al., 1990) and alder seedlings (Tschaplinski and Blake, 1985).

The main consequence of the reduced root growth is a subsequent decrease of shoot growth (Liu and Latimer, 1995; Hsu et al., 1996; Young et al., 1997; Hee Choi et al., 1997), because a restricted root system will supply insufficient water (Hameed et al., 1987; Tschaplinski and Blake, 1988; Ran et al., 1992) and nutrients (Hanson et al., 1987; Dubik et al., 1990; Rieger and Marra, 1994) to the shoot. As a result of root restriction, shoot growth may also be limited by insufficient carbon supply, because more carbon may be required by roots for increased osmotic pressure (Greacen and Oh, 1972). Also, a reduction in the root "sink" as a result of root restriction can cause carbohydrates to accumulate in the leaves, resulting in a feedback inhibition of photosynthesis (Arp, 1991; Schaffer et al., 1996).

In a previous paper we examined the effects of root restriction on shoot growth (Yamanishi et al., 1998). In the present study we determine the effect of soil resistance to root penetration on gas-exchange of four papaya genotypes grown under field conditions.

\section{MATERIALS AND METHODS}

\section{Plant material and growth conditions}

Experiments were conducted at Macaé Experimental Station, Empresa de Pesquisa Agropecuária do Estado do Rio de Janeiro (PESAGRO-RIO/EEM, Macaé-Brazil, lat. $22^{0} 24^{\prime}$ S, long. $41^{0} 42^{\prime} \mathrm{W}$ ). Four papaya genotypes, two from the 'Solo' group (Sunrise Solo TJ and Improved Sunrise Solo line 72/12) and two from 'Formosa' group (Tainung 02 and Know-You 01) were grown in ultisol under field conditions at two distinct effective depths $(E D)$ (thickness of the A horizon). The $E D$ was determined using a penetrographer SC-60, cone/axe standard American Society Agricultural Engineers, solid angle cone with $60^{\circ}$, base area $129.0 \mathrm{~mm}^{2}$ and 9.5 $\mathrm{mm}$ diameter of the axis (Soilcontrol, Santo Amaro, São Paulo, Brazil). The average soil 
moisture during the measurements was $11.2 \pm$ $2.50 \%$. Area with $34,5 \mathrm{~cm} \mathrm{ED}$ and maximum pressure of 4.12 MPa for penetration was defined as an area with restriction $(W R)$ to root growth, while, the area with minimum $E D$ of $60.0 \mathrm{~cm}$ with pressure lower than $2.30 \mathrm{MPa}$ as an area with no restriction (NR) (Unger and Kaspar, 1994). The soil textural class, bulk density, particle density, porosity and macroporosity of the soil were classified according to EMBRAPA (1997).

The experimental area was fertilized and the $\mathrm{pH}$ adjusted according to Marin et al., (1993). Throughout the experiment the plants were subjected to periodic sprinkle irrigation to keep the soil moisture close to field capacity.

\section{Determination of the physiological characteristics}

The net $\mathrm{CO}_{2}$ assimilation rate $(A)$, stomatal conductance $\left(g_{s}\right)$, leaf temperature $\left(T_{l}\right)$ and intercellular partial pressure of $\mathrm{CO}_{2}\left(\mathrm{c}_{\mathrm{i}}\right)$ were evaluated on 28, 29 and of 30 March [150 days after transplanting (DAT)], respectively as the first, second and third day after irrigation, in leaves grown in full sunlight using a portable photosynthesis system (LI-6200; LI-COR Inc., Lincoln, NE, USA) on four trees in each treatment. Plants were transplanted 45 days after seed germination. Data was collect from 9:00 to 11:00 h using the seventh leaf from the apex. Intrinsic water use efficiency (IWUE) was calculated as the slope of the linear portion of the regression line of $A$ vs. $g_{s}$ for each genotype in each of the two tratments (Martin et al., 1994; Pimentel et al., 1999). Soil moisture was determined in the first, second and third days after irrigation by a gravimetric method (Bernardo, 1995).

\section{Data analysis}

Results were statistically analyzed according to genotype and soil mechanical resistance as a randomized design, each with four replications. Analysis of variance was determined using Statistica (Statsoft, Inc., Tulsa, OK, USA). Duncan`s Multiple Range Test ( $p$ 0.05) was used to determine difference among means. Significant differences in IWUE between $W R$ and $N R$ of each genotype were determined by testing for homogeneity of slopes ("T"-test) (Minitab, Inc., State College, PA, USA).

\section{RESULTS AND DISCUSSION}

Significant difference in $E D$ among $N R$ and $W R$ areas was found using a penetrographer. The $N R$ area had a deeper $E D,>0.60 \mathrm{~m} \quad(<2.30$ $\mathrm{MPa}$ ), compared with $\leq 0.35 \mathrm{~m}$ (maximum of 4.12 $\mathrm{MPa}$ ) in the $W R$ one. Roots of several species are highly sensitive to the resistance imposed by physical characteristics of the soil, and plant growth is inhibited or completely stopped when resistance to the penetration exceeded $2.5 \mathrm{MPa}$ (Unger and Kaspar, 1994). Soil macroporosity in $\boldsymbol{B}$ horizon was lower than $\boldsymbol{A}$ horizon indicating the presence of a physical alteration in the $\boldsymbol{B}$ horizon (Table 1). When soil is submitted to this type of physical alteration, the macroporosity decreases and roots cannot penetrate the small pores (Wiersum, 1957). In this case, the rate of root growth is reduced to extremely low levels or ceases (Marschner, 1995). In addition, the $N R$ area presented a deeper $\boldsymbol{A}$ horizon without compactation zone which provided better conditions for root growth compared to a thinner $\boldsymbol{A}$ horizon with compactation zone that restricted the root growth in $W R$ area (Campostrini et al., 1997). This may explain the reduced root growth in plants grown in WR area (Campostrini et al., 1997).

All genotypes grown in the $W R$ area had lower $A, g_{s}$ than genotypes in the $N R$ area (Tables 2 to 4). Masle and Passioura (1987) and Lipiec et al., (1996) observed significant reductions of $g_{s}$ in plants grown in soil with high mechanical impedance. If the stomatal movements affect the partial pressure of $\mathrm{CO}_{2}$ at the sites of carboxylation and the rate of transpiration (Farquhar and Sharkey, 1982), the correlation between $A$ and $g_{s}$ (Figure 1) can be explained as a function of the high concentration of $\mathrm{CO}_{2}$ in the sites of carboxylation when $g_{s}$ increases (Farquhar and Sharkey, 1982, Krieg and Hutmacher, 1986, Mansfield et al., 1990, Lawlor, 1993, Martin et al., 
1994). This correlation is verified when no other factor limits the light reactions and biochemistry.

The reduced values of $A$ in the $W R$ area cannot be justified by the reduced stomatal density, because the abaxial stomatal density was the same in all plants (data not shown).

TABLE 1 - Textural class, bulk density, particle density, porosity and macroporosity of the soil in Macaé/RJ/Brazil

\begin{tabular}{cccc} 
Horizon & $\begin{array}{c}\mathrm{B}_{\mathrm{d}}^{\mathrm{z}} \\
\left(\mathrm{g} \mathrm{cm}^{-3}\right)\end{array}$ & $\begin{array}{c}\mathrm{P}_{\mathrm{dr}}^{\mathrm{y}} \\
\left(\mathrm{g} \mathrm{cm}^{-3}\right)\end{array}$ & Poil \\
& & & $(\%)$ \\
\hline
\end{tabular}

\begin{tabular}{ccccc}
$\mathrm{A}^{\mathrm{w}}$ & 1.74 & 2.60 & 33.1 & 13.3 \\
$\begin{array}{c}\text { (sandy- } \\
\text { loam) }\end{array}$ & & & & \\
$\mathrm{B}^{\mathrm{v}}$ & 1.64 & 2.61 & 37.2 & 7.9 \\
(clay) & & & & \\
\hline
\end{tabular}

$\mathrm{B}_{\mathrm{d}}{ }^{\mathrm{z}}=$ Bulk Density, $\mathrm{P}_{\mathrm{d}}^{\mathrm{y}}=$ Particle Density, Macroporosity ${ }^{\mathrm{x}}(0.1 \mathrm{~atm})$, (sandy-loam, 58\% coarse, $15 \%$ fine sandy, $07 \%$ silt and $20 \%$ clay) ${ }^{\mathrm{w}}$, (clay, $25 \%$ coarse, $19 \%$ fine sandy, $08 \%$ silt and $48 \%$ clay $)^{\mathrm{v}}$.

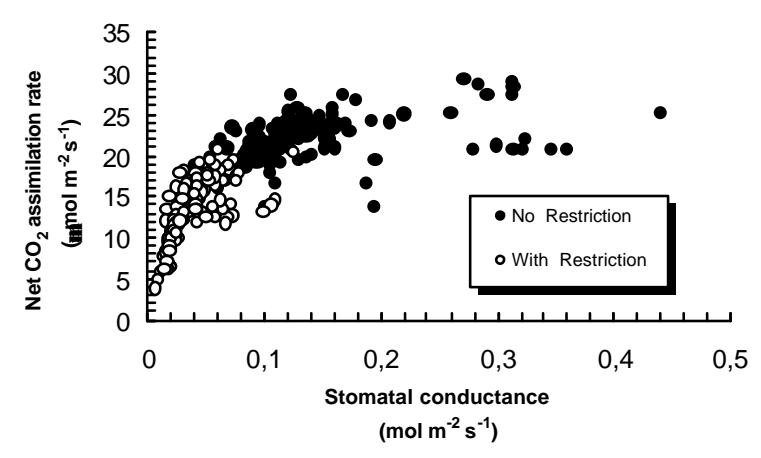

FIGURE 1 - Relationship between stomatal conductance $\left(g_{s}\right)$ and net $\mathrm{CO}_{2}$ assimilation rate $(A)$ of four papaya (Carica papaya L.) genotypes as influenced by root zone restriction in Macaé/RJ/Brazil.
In conditions of physical impedance of the soil to the root system, several studies mentioned an increase in the concentration of abscisic acid (ABA) in the exudate of the xylem (Tardieu et al., 1991, Hartung et al., 1994, Liu and Latimer, 1995). Probably, the reduced stomatal conductance observed in leaves of $W R$ plants is probably due to the increase in the levels of $\mathrm{ABA}$ produced by the roots and transported to the shoot by the transpiration process by xylem sap. Further studies are required to give more insight to $\mathrm{ABA}$ function in stomatal conductance in papaya plants. On the other hand, Hameed et al., (1987) proposed that, under conditions of root system restriction, plants are subjected to water stress when cultivated in a nutrient solution. These authors explained that the stress induction was caused by a high hydraulic resistance in the roots, which reduced the absorption and the translocation of water to the shoot

Plants water deficits generally occur as a result of either soil water or atmospheric water deficit or both (Flore and Lakso, 1988). Although the atmospheric component is important in all plants (Schulze, 1986), it is particularly important in fruit trees such as papaya (El-Sharkawy et al., 1985). This is due to the very low hydraulic condutivity of root systems that causes a pronounced effect of transpiration on water potentials in the top of the tree (Jones et al., 1985). Consequently, the regulation of leaf water status by atmospheric conditions is relatively more important in fruit trees than in other crops, specially annuals, that have much higher root conductivities (Flore and Lakso, 1988). This means that leaf water status of fruit crops is strongly dependent on the evaporative demand of the atmosphere. The leaf water status will vary much more diurnally than in many annuals, and leaf water stresses may occur under high evaporative demands even though soil water is adequate. Consequently, stomatal response to humidity is particularly important in fruit crops (Flore and Lakso, 1988). For this reason atmospheric factors that regulate leaf water 
status and photosynthesis should be considered as well as those that those that regulate soil water deficits when evaluating fruit tree physiology (Flore and Lakso, 1988). If plants grown under conditions of root system restriction had a high hydraulic resistance in the roots (Hameed et al., 1987), the papaya genotypes grown in the WR area seemed to have experienced a high leaf water stress due to a high vapour pressure deficit (summer) at measuring time than genotypes in the NR area. This condition may have contributed to a significant decrease in stomatal opening followed by reduced $A$ values of papaya leaves in $W R$ area (Table 2 to 4). Possibly, the mechanical root restriction increased the effects of atmospheric components in plants grown in $W R$ area.
Although it also showed a considerable reduction in gas exchange rates, the Know-You genotype was the least affected by root restriction (Tables 2 to 4). It presented the highest values of of $A$ and $g_{s}$ in the WR area in the three consecutive days that the plants were not irrigated. This genotype had the greatest leaf area of the four genotypes in the WR area (Yamanishi et al., 1998). Notwithstanding the greatest evaporative surface area, it was able to extract enough water from the soil to maintain a high stomatal conductance than the other genotypes in the $W R$ area. Future research on this genotype should be conducted in order to study the effects of the root mechanical restriction in relation to stomatal conductance and root hydraulic conductance.

TABLE 2 - Net $\mathrm{CO}_{2}$ assimilation rate $(A)$, stomatal conductance $\left(g_{s}\right)$, intercellular partial pressure $\mathrm{CO}_{2}$ $\left(c_{i}\right)$ and leaf temperature $\left(T_{l}\right)$ of four papaya (Carica papaya L.) genotypes as influenced by root zone restriction in Macaé/RJ/Brazil. Determined in the first day after the irrigation.

\begin{tabular}{|c|c|c|c|c|c|c|c|c|}
\hline \multirow{3}{*}{ Genotypes } & \multicolumn{2}{|c|}{$A^{z}$} & \multicolumn{2}{|c|}{$\mathrm{g}_{\mathrm{s}}^{\mathrm{z}}$} & \multicolumn{2}{|c|}{$c_{i}^{\mathrm{z}}$} & \multicolumn{2}{|r|}{$\mathrm{T}_{1}^{\mathrm{z}}$} \\
\hline & \multicolumn{2}{|c|}{$\left(\mu \mathrm{mol} \mathrm{m}{ }^{-2} \mathrm{~s}^{-1}\right)$} & \multicolumn{2}{|c|}{$\left(\mathrm{mol} \mathrm{m}{ }^{-2} \mathrm{~s}^{-1}\right)$} & \multicolumn{2}{|c|}{$\left(\mu L^{-1}\right)$} & \multicolumn{2}{|c|}{$\left({ }^{\circ} \mathrm{C}\right)$} \\
\hline & $\mathrm{NR}^{\mathrm{y}}$ & $\mathrm{WR}^{\mathrm{x}}$ & NR & WR & NR & WR & NR & WR \\
\hline Sunrise Solo TJ & $24.2 \mathrm{Aab}^{\mathrm{w}}$ & $14.3 \mathrm{Bb}$ & $0.155 \mathrm{Ab}$ & $0.031 \mathrm{Bb}$ & $262.6 \mathrm{Aa}$ & $232.3 \mathrm{Ba}$ & $36.5 \mathrm{Bb}$ & $40.0 \mathrm{Aa}$ \\
\hline Sunrise Solo 72/12 & $20.8 \mathrm{Ac}$ & $13.8 \mathrm{Bb}$ & $0.093 \mathrm{Ab}$ & $0.039 \mathrm{Bb}$ & $251.3 \mathrm{Ab}$ & $230.9 \mathrm{Aa}$ & $37.8 \mathrm{Ba}$ & $39.2 \mathrm{Aa}$ \\
\hline Tainung 02 & $25.8 \mathrm{Aa}$ & $12.7 \mathrm{Bb}$ & $0.292 \mathrm{Aa}$ & $0.036 \mathrm{Bb}$ & 261.7 Aa & $245.9 \mathrm{Ba}$ & $36.6 \mathrm{Ab}$ & $37.8 \mathrm{Ab}$ \\
\hline Know -You 01 & $23.3 \mathrm{Ab}$ & $16.8 \mathrm{Ba}$ & $0.131 \mathrm{Ab}$ & $0.067 \mathrm{Ba}$ & 259.7Aab & 253.0Aa & $36.7 \mathrm{Bb}$ & $38.1 \mathrm{Ab}$ \\
\hline
\end{tabular}

${ }^{\mathrm{z}}$ Determined at hundred fifty days after transplant, first day after irrigation; Photosynthetic photon flux $2141.0 \pm$ $298.0 \mu \mathrm{mol} \mathrm{m} \mathrm{m}^{-1}$. Data collected at 9:00-11:00 AM. Air Temperature 38.08 $\pm 0.97^{\circ} \mathrm{C}$. $\mathrm{CO}_{2}$ concentration into chamber $331.50 \pm 9.46 \mu \mathrm{L} \mathrm{L}^{-1}$. Partial pressure of water vapour into chamber $3.57 \pm 0.207 \mathrm{kPa}$; Soil moisture on volume basis $11.01 \pm 1.72 \%$, [Field Capacity $=11.00 \%$ ]; ${ }^{\mathrm{y}} \mathrm{NR}=$ Area with no restriction to root growth; ${ }^{\mathrm{x}} \mathrm{WR}=\mathrm{Area}$ with restriction of the growth root system; ${ }^{\mathrm{w}}$ The columns and lines, average followed by the same small or capital letters for each analyzed characteristic did not differ at level of 5\% (p 0.05) of probability using the Duncan's Multiple Range Test. 
TABLE 3 - Net $\mathrm{CO}_{2}$ assimilation rate $(A)$, stomatal conductance $\left(g_{s}\right)$, intercellular partial pressure $\mathrm{CO}_{2}$ $\left(c_{i}\right)$ and leaf temperature $\left(T_{l}\right)$ of four papaya (Carica papaya L.) genotypes as influenced by root zone restriction in Macaé/RJ/Brazil. Determined in the second day after the irrigation.

\begin{tabular}{|c|c|c|c|c|c|c|c|c|}
\hline \multirow{2}{*}{ Genotypes } & \multicolumn{2}{|c|}{$\mathrm{A}^{\mathrm{z}}\left(\mu \mathrm{mol} \mathrm{m} \mathrm{m}^{-2} \mathrm{~s}^{-1}\right)$} & \multicolumn{2}{|c|}{$\mathrm{gs}_{\mathrm{s}}^{\mathrm{Z}}\left(\mathrm{mol} \mathrm{m} \mathrm{s}^{-2} \mathrm{~s}^{-1}\right)$} & \multicolumn{2}{|c|}{$c_{i}^{\mathrm{z}}\left(\mu \mathrm{L} \mathrm{L}^{-1}\right)$} & \multicolumn{2}{|c|}{$\mathrm{T}_{\mathrm{l}}^{\mathrm{z}}\left({ }^{\circ} \mathrm{C}\right)$} \\
\hline & $\mathrm{NR}^{\mathrm{y}}$ & $\mathrm{WR}^{\mathrm{x}}$ & NR & WR & NR & WR & NR & WR \\
\hline Sunrise Solo TJ & $21.3 \mathrm{Aa}^{\mathrm{w}}$ & $14.0 \mathrm{Bb}$ & $0.123 \mathrm{Ac}$ & $0.034 \mathrm{Ba}$ & $278.0 \mathrm{Aa}$ & $252.5 \mathrm{Bc}$ & 37.1Aab & $37.3 \mathrm{Ab}$ \\
\hline Su.nrise Solo 72/12 & $20.2 \mathrm{Aa}$ & $11.2 \mathrm{Bc}$ & $0.223 \mathrm{Aab}$ & $0.037 \mathrm{Ba}$ & $273.9 \mathrm{Aa}$ & $267.3 \mathrm{Ab}$ & $37.7 \mathrm{Ba}$ & $39.0 \mathrm{Aa}$ \\
\hline Tainung 02 & $22.0 \mathrm{Aa}$ & 15.0 Bab & $0.181 \mathrm{Abc}$ & $0.062 \mathrm{Ba}$ & $274.0 \mathrm{Ba}$ & $295.0 \mathrm{Aa}$ & $36.7 \mathrm{Ab}$ & $34.5 \mathrm{Bc}$ \\
\hline Know -You 01 & $22.6 \mathrm{Aa}$ & $16.6 \mathrm{Ba}$ & $0.249 \mathrm{Aa}$ & $0.081 \mathrm{Ba}$ & $268.0 \mathrm{Aa}$ & $276.0 \mathrm{Ab}$ & $36.7 \mathrm{Ab}$ & $37.0 \mathrm{Ab}$ \\
\hline
\end{tabular}

${ }^{\mathrm{z}}$ Determined 150 days after transplanting, on the second day after irrigation; Quantum flux of photons $2084.0 \pm 71.20$ $\mu \mathrm{mol} \mathrm{m} \mathrm{m}^{-1}$. Data collected at 9:00-11:00 AM. Air Temperature 37.0 $\pm 1.46^{\circ} \mathrm{C} . \mathrm{CO}_{2}$ concentration into chamber $345.79 \pm$ $18.60 \mu \mathrm{L} \mathrm{L}^{-1}$. Partial pressure of water vapour into chamber $3.50 \pm 0.266 \mathrm{kPa}$; Soil moisture on volume basis $10.00 \pm$ $1.15 \%$, [Field Capacity $=11.00 \%$ ]; ${ }^{\mathrm{y}} \mathrm{NR}=$ Area with no restriction to root growth; ${ }^{\mathrm{x}} \mathrm{WR}=$ Area with restriction of the root growth; ${ }^{\text {w }}$ Averages followed by the same small letters in the columns or capital letters in the rows (for each characteristic) did not differ at the probability level of 5\% (p 0.05) using the Duncan's Multiple Range Test.

TABLE 4 - Net $\mathrm{CO}_{2}$ assimilation rate $(A)$, stomatal conductance $\left(g_{s}\right)$, intercellular partial pressure $\mathrm{CO}_{2}$ $\left(c_{i}\right)$ and leaf temperature $\left(T_{l}\right)$ of four papaya (Carica papaya L.) genotypes as influenced by root zone restriction in Macaé/RJ/Brazil. Determined in the third day after the irrigation.

\begin{tabular}{|c|c|c|c|c|c|c|c|c|}
\hline \multirow{2}{*}{ Genotypes } & \multicolumn{2}{|c|}{$\mathrm{A}^{\mathrm{Z}}\left(\mu \mathrm{mol} \mathrm{m} \mathrm{m}^{-2} \mathrm{~s}^{-1}\right)$} & \multicolumn{2}{|c|}{$\mathrm{gs}_{\mathrm{s}}^{\mathrm{z}}\left(\mathrm{mol} \mathrm{m} \mathrm{m}^{-2} \mathrm{~s}^{-1}\right)$} & \multicolumn{2}{|c|}{$c_{i}^{\mathrm{Z}}\left(\mu \mathrm{LL}^{-1}\right)$} & \multicolumn{2}{|c|}{$\mathrm{T}_{1}^{\mathrm{z}}\left({ }^{\circ} \mathrm{C}\right)$} \\
\hline & $\mathrm{NR}^{y}$ & $\mathrm{WR}^{\mathrm{x}}$ & NR & WR & NR & WR & NR & WR \\
\hline Sunrise Solo TJ & $17.1 \mathrm{Aa}^{\mathrm{w}}$ & $10.0 \mathrm{Bb}$ & $0.110 \mathrm{Ab}$ & $0.021 \mathrm{Ba}$ & $282.1 \mathrm{Ac}$ & $261.4 \mathrm{Bb}$ & $36.7 \mathrm{Ba}$ & $38.1 \mathrm{Aa}$ \\
\hline Sunrise Solo 72/12 & $22.0 \mathrm{Aa}$ & $11.5 \mathrm{Bb}$ & $0.226 \mathrm{~A} \mathrm{a}$ & $0.052 \mathrm{Ba}$ & $296.7 \mathrm{Ab}$ & 271.3 Bab & $35.3 \mathrm{Bb}$ & $36.5 \mathrm{Ad}$ \\
\hline Tainung 02 & $22.2 \mathrm{Aa}$ & 12.3 Bab & $0.131 \mathrm{Ab}$ & $0.029 \mathrm{Ba}$ & $309.4 \mathrm{Aa}$ & $276.8 \mathrm{Ba}$ & $36.8 \mathrm{Ba}$ & $37.6 \mathrm{Ab}$ \\
\hline Know -You 01 & $21.8 \mathrm{Aa}$ & $15.2 \mathrm{Ba}$ & $0.210 \mathrm{Aa}$ & $0.062 \mathrm{Ba}$ & 293.2 Abc & $282.8 \mathrm{Aa}$ & $35.7 \mathrm{Bab}$ & 37.8 Aab \\
\hline
\end{tabular}

${ }^{\mathrm{z}}$ Determined 150 days after transplanting, on third day after irrigation; Quantum flux of photons $1650.60 \pm 160.90$ $\mu \mathrm{mol} \mathrm{m} \mathrm{m}^{-2}$. Data collected at 9:00-11:00 AM. Air Temperature 36.90 $\pm 0.8^{\circ} \mathrm{C} . \mathrm{CO}_{2}$ concentration into chamber $360.00 \pm 11.70 \mu \mathrm{L} \mathrm{L}^{-1}$. Partial pressure of water vapour into chamber $3.59 \pm 0.11 \mathrm{kPa}$; Soil moisture on volume basis $9.36 \pm 1.73 \%$, [Field Capacity $=11.00 \%$ ]; ${ }^{y} \mathrm{NR}=$ Area with no restriction to root growth, ${ }^{\mathrm{x}} \mathrm{WR}=$ Area with restriction of root growth; ${ }^{\mathrm{w}}$ Average followed by the same small letters in columns or capital letters in the rows (for each characteristic) did not differ at the probability level of 5\% ( $\mathrm{p}<0.05)$ using Duncan's Multiple Range Test. 
The reduction in the $g_{s}$ verified in the leaves of all genotypes in the $W R$ area may have contributed to increase the $T_{l}$ except for Tainung 02 on the second day after irrigation. As $T_{l}$ is related to $E$ (Nobel, 1991), plants grown in the $W R$ area showed reduced $g_{s}$, and as a result of the limited $E$ increased $T_{l}$ (Tables 2 to 4 ).

The high concentration of $\mathrm{CO}_{2}$ in the intercellular space $(\mathrm{ci})$, for all genotypes grown at $N R$ area, during the three days after irrigation (Tables 2 to 4 ), was caused by high $g_{s}$ values in the $N R$ area, since $c_{i}$ is directly proportional to the stomatal conductance and inversely proportional to $A \quad\left(c_{i}=C_{a}-A / g_{s}\right)$, for constant values of the concentration $\mathrm{CO}_{2}$ in the bulk air $\left(C_{a}\right)$ (Mansfield et al., 1990, Field et al., 1990, Long and Hällgren, 1993, Farquhar and Sharkey, 1982). The contrasting results for the genotypes Tainung 02 and Know-You 01 on the second day after the irrigation were due to the high values of the $\mathrm{CO}_{2}$ concentration in the bulk air at the measurement time of the two genotypes. However, these genotypes grown in the $N R$ area had larger rates of $A$ that contributed to reduced concentration of $\mathrm{CO}_{2}$ in the leaf intercellular air spaces. These elevated $A$ values for genotypes grown in the NR area were not sufficient to reduce the $c_{i}$. The high $c_{i}$ of Tainung 02 and Know-You 01 was caused by the high stomatal conductance.

The values of the IWUE in all genotypes were higher in the $W R$ area than in the $N R$ area (Table 5). These elevated values can be explained by the much larger reductions in $g_{s}$ than in $A$ in plants grown in the $W R$ area. This fact may explain the high IWUE in Sunrise Solo TJ, since this genotype presented the smallest $g_{s}$ values in this area. This adjustment in the $g_{s}$, reducing the values of $A$ is a possible mechanism that facilitates the acclimatization of the plant exposed to a limiting factor. This acclimatization allow plants to continue incorporating carbon to the biomass, avoiding the excessive loss of water. Possibly, the genotype Sunrise Solo TJ presents a high efficiency in the stomatal adjustment compared to other genotypes.
TABLE 5 - Intrinsic water use efficiency (IWUE) of four papaya (Carica papaya L.) genotypes as influenced by root zone restriction in Macaé/RJ/Brazil

\begin{tabular}{lcc}
\hline \multicolumn{1}{c}{ Genotypes } & \multicolumn{2}{c}{$\operatorname{IWUE}^{\mathrm{z}}\left(\mu \mathrm{mol} \mathrm{\textrm {mol } ^ { - 1 } )}\right.$} \\
\cline { 2 - 3 } $\mathrm{NR}^{\mathrm{y}}$ & $\mathrm{WR}^{\mathrm{x}}$ \\
\hline Sunrise Solo TJ & $70.6 \mathrm{Ba}^{\mathrm{w}}$ & $398.4 \mathrm{Aa}$ \\
Sunrise Solo 72/12 & $44.4 \mathrm{Ba}$ & $259.4 \mathrm{Ab}$ \\
Tainung 02 & $66.9 \mathrm{Ba}$ & $271.6 \mathrm{Ab}$ \\
Know -You 01 & $39.5 \mathrm{Ba}$ & $167.9 \mathrm{Ac}$ \\
\hline
\end{tabular}

${ }^{\mathrm{z}}$ Determinated using data $A$ and $g_{s}$ collected in the first, second and thirth days after irrigation; ${ }^{\mathrm{y}} \mathrm{NR}=$ Area with no restriction to root growth; ${ }^{x} \mathrm{WR}=$ Area with restriction of root growth; ${ }^{\text {w }}$ Average followed by the same small letters in columns or capital letters in the rows did not differ at the probability level of 5\% $(\mathrm{p}<0.05)$ using the Duncan's Multiple Range Test.

Root system restriction, imposed by soil, impaired some physiological characteristics of the four papaya genotypes studied. All genotypes presented higher values of $I W U E$ in plants grown in $W R$ area where Sunrise Solo TJ showed the highest IWUE. Further investigations are required to understand if the stomata closure in papaya plants growing in soil with mechanical impedance is due to a hormonal effect or reduced leaf water potential caused by high vapour pressure deficit and/or high hydraulic resistance in the roots.

\section{REFERENCES}

ARP, W.J. Effects of source-sink relations on photosynthetic acclimation to elevated $\mathrm{CO}_{2}$. Plant, Cell and Environment, 14: 869-875, 1991. 
BERNARDO, S. Manual de irrigação. Viçosa, Imprensa Universitária, UFV, 1995.657p.

CAMPOSTRINI, E. Comportamento de quatro genótipos de mamoeiro (Carica papaya L.) sob restrição mecânica ao crescimento do sistema radicular. Campos dos Goytacazes, Universidade Estadual do Norte Fluminense, 1997. 166p. Tese de Doutorado.

DUBIK, S.P.; KRIZEK, D.P. \& STIMART, D.P. Influence of root zone restriction on mineral element concentration, water potential, chlorophyll concentration, and partitioning of assimilate in spreading euonymus (E. kiautschovica loes. 'Sieboldiana'. Journal Plant Nutrition, 13:677-699, 1990.

El-SHARKAWY, M.; COCK, J. H. \& HERNANDEZ, A. D. P. Stomatal response to air humidity and its relation to stomatal density in a wide range of warm climate species. Photosynthesis Research, p. 137-149. 1985

EMBRAPA. Manual de métodos de análise de solo. Centro de Nacional de Pesquisas de Solo. Rio de Janeiro. 1997. 212p

FARQUHAR, G. \& SHARKEY, T.D. Stomatal conductance and photosynthesis. Annual Review Plant Physiology, 33 p.317-345,1982.

FIELD, C.B.; BALL, T. \& BERRY, J. Photosynthesis: principles and field techniques. In: PEARCY, R.W., EHLERINGER, J.R., MOONEY, H.A., RUNDEL, P.W. (Eds.) Plant physiological ecology. New York, Chapman and Hall, 1989, p.209-248.

FLORE, J.A. \& LAKSO, A.N. Environmental and physiological regulation of photosynthesis in fruit crops. Horticultural Reviews, 11, p. 111157,1988

GREACEN, E.L \& OH, J.S. Physics of root growth. Nature New Biology, 235, p. 24-25, 1972.
HAMEED, M.A.; REID, J.B. \& ROWE, R.N. Root confinement and its effects on the water relations, growth and assimilate partitioning of tomato (Lycopersicun esculentum Mill). Annals of Botany, 59, p. 685-692,1987

HANSON, P.J.; DIXON, R.K. \& DICKENSON, R.E.. Effect of container size and shape on the growth of northern red oak seedlings. HortScience, 22, p.1293-1295, 1987

HARTUNG, W.; ZHANG, J. \& DAVIES, W.. Does abscisic acid play a stress physiological role in maize plants growing in heavily compacted soil? Journal of Experimental Botany, 45, p. 221-226, 1994.

HEE CHOI, J.; CHAE CHUNG, G.; RYONG SUH, S.; AH YU, J.; HOON SUNG, J. \& JU, K. Suppression of calcium transport to shoots by root restriction in tomato plants. Plant Cell Physiology, 38, p. 495-498, 1997.

HSU, Y.M.; TSENG, M.J. \& LIN, C.H.. Container volume effects growth and development of wax-apple. HortScience, 31, p. 1139-1142. 1996

JONES, H.G.; LAKSO, A.N.\& SYVERTSEN, J.P. Physiological control of water status in temperate and subtropical fruit trees. Horticultural Reviews , 7, p. 301-344, 1985

KRIEG, D.R. \& HUTMACHER, R.B. Photosynthetic rate control in sorghum: stomatal and nonstomatal factors. Crop Science, 26, p.112-117, 1986.

LAWLOR, D.W. Photosynthesis: molecular, physiological and environmental process. Essex, Longman Scientific and Technical, 1993. 318p.

LIPIEC, J.; TOMOHIRO, I.; SZUSTAK, A.; PIETRUSIEWICZ, J. \& STEPNIEWSKI, W. Effects of soil compaction and transient oxygen deficiency on growth, water use and stomatal resistence of maize. Acta Agriculturae Scandinavica Sect. B, Soil and Plant Science, 46, p. 186-191, 1996. 
LIU, A. \& LATIMER, J.G. Water relations and abscisic acid levels of watermelon as affected by rooting volume restriction. Journal of Experimental Botany, 46, p.1011-1015, 1995.

LONG, S.P. \& HÄLLGREN, J.E. Measurement of $\mathrm{CO}_{2}$ assimilation by plants in the field and the laboratory. In: HALL, D.O.; SCURLOCK, H.R.; BOLHÀR-NORDENDAMPF, H.R.; LEEGOOD, R.C.; LONG, S.P. (Eds.) Photosynthesis and production in a changing environment. A field and laboratory manual . London, Chapman and Hall, 1993, p.129-165.

MANSFIELD, T.A.; HETHERINGTON, A.M. \& ATKINSON, C.J. Some current aspects of stomatal physiology. Annual Review Plant Physiology, 41, p. 55-75, 1990.

MARIN, S.L.D.; GOMES, J.A.; SALGADO, J.S.; MARTINS, D.S. \& FULLIN, E.A. Recomendações para a cultura do mamoeiro dos grupos 'Solo' e 'Formosa' no Estado do Espírito Santo. Vitória, Emcapa, 1993. (Circular Técnica, 3).

MARSCHNER, H. Mineral nutrition of higher plants, London, Academic Press, 1995. 889p.

MARTIN, B.; KEBEDE, H. E RILLING, C. Photosynthetic differences among Lycopersicon species and Triticum aestivum cultivars. Crop Science, 34, p.113-118, 1994.

MASLE, J. \& PASSIOURA, J.B. The effect of soil strength on the growth of young wheat plants. Australian Journal Plant Physiology, 14, p. 643-956, 1987.

MISRA, R.K. \& GIBBONS, A.K. Growth and morphology of eucalypt seedling-roots, in relation to soil strength arising from compaction. Plant and Soil, 182, p. 1-11, 1996.

NOBEL, P.S. Physicochemical and environmental plant physiology, San Diego, Academic Press, 1991.635p.
PIMENTEL, C.; LAFFRAY, D. \& LOUGUET, P. Intrinsic water use efficiency at the pollination stage as a parameter for drought tolerance selection in Phaseolus vulgaris. Physiologia Plantarum, 106, p.184-189. 1999

RAN, Y.; BAR-YOSEF, B. \& EREZ, A.. Root volume influence on dry matter production and partitioning as related to nitrogen and water uptake rates by peach tree. Journal of Plant Nutrition, 15:713-726, 1992.

RESENDE, M.; CURI, N. \& SANTANA, D.P. Pedologia e fertilidade do solo: Interações e aplicações. Brasília, MEC. 1988. 200p.

RICHARDS, D. \& ROWE, R.N. Effects of root restriction, root pruning, and 6benzylaminopurine on the growth of peach seedlings. Annals of Botany, 41, p.729-740, 1977.

RIEGER, M. \& MARRA, F. Responses of young peach trees to root confinement. Journal of the American Society for Horticultural Science, 119, p. 223-228, 1994.

SCHAFFER, B.C.; SEARLE, C.; WHILEY, A.W. \& NISSEN, R.J.. Effects of atmospheric $\mathrm{CO}_{2}$ enrichment and root restriction on leaf gas exchange and growth of banana (Musa). Physiologia Plantarum, 97, p. 685-693, 1996.

SCHULZE, E.D. Carbon dioxide and water vapor exchange in response to drought in the atmosphere and in the soil. Annual Review Plant Physiology, 37, p.247-274, 1986.

TARDIEU, F.; KATERJI, N.; BETHENOD, O; ZHANG, J. \& DAVIES, W.J. Maize estomatal conductance in the field: its relationship with soil and plant water potentials, mechanical constraints and $\mathrm{ABA}$ concentration in the xylem sap. Plant, Cell and Environment, 14, p.121126, 1991. 
TSCHAPLINSKI, T.J. \& BLAKE, T.J. Effects of root restriction on growth correlations, water relations and senescence of alder seedlings. Physiologia Plantarum, 64, p.167-176, 1985.

UNGER, P.W. \& KASPAR, T. Soil compaction and root growth: a review. Agronomy Journal, 86, p.759-766, 1994.

WIERSUM, L.K.. The relationship of the size and structural rigidity of pores to their penetration by roots. Plant and Soil, 9, p.75-85, 1957.
YAMANISHI, O.K.; CAMPOSTRINI, E.; MARIN, S.L.D. \& MARTELLETO, L.A.P. Influence of root restriction on the growth of four papaya (Carica papaya L.) genotypes. Acta Horticulturae, 516, p. 155-162, 1998.

YOUNG, I.M.; MONTAGU, K. \& CONROY, J.A.G. Mechanical impedance of root growth directly reduces leaf elongation rates of cereals. New Phytologist, 135, p. 613-619, 1997. 